\title{
Pengaruh Model Pembelajaran Terhadap Hasil Belajar IPS Siswa Kelas VII SMP Negeri di Kecamatan Gunungpati
}

\author{
Mifta Husni Choirun Nisa, Arif Purnomo, Noviani Achmad Putri ${ }^{\bowtie}$
}

Social Science Education Department, Faculty of Social Science, Universitas Negeri Semarang, Indonesia

\section{Info Artikel}

Sejarah Artikel:

Disubmit Januari 2019

Direvisi Februari 2019

Diterima Maret 2019

\section{Keywords:}

learning model; social learning; outcome; influence of education learning model

\begin{abstract}
Abstrak
Tujuan penelitian ini adalah untuk mengetahui model pembelajaran yang digunakan guru, hasil belajar, serta pengaruh model pembelajaran yang digunakan guru terhadap hasil belajar IPS Kelas VII SMP Negeri di Kecamatan Gunungpati. Peneliti menggunakan pendekatan kuantitatif. Objek penelitian meliputi Peserta didik dan guru kelas VII SMP Negeri di Kecamatan Gunungpati. Pendekatan yang digunakan dalam penelitian ini ialah Kuantitatif Ex-Post Facto. Metode pengumpulan data yang digunakan berupa angket dan dokumentasi. Sedangkan teknik analisis data yang digunakan ialah analisis regresi. Hasil penelitian menunjukan bahwa terdapat pengaruh antara model pembelajaran yang digunakan guru terhadap hasil belajar siswa kelas VII SMP Negeri di Kecamatan Gunungpati. Hasil perhitungan analisis regresi sederhana dengan persamaan didapatkan nilai $\mathrm{a}=48,504$ dan $\mathrm{b}=0,364$ sehingga dengan menggunakan rumus persamaan regresi linier sederhana sebagai berikut. $\hat{Y}=48,504+0,364 \mathrm{X}$. Sedangkan Siswa hendaknya mampu memanfaatkan fasilitas sekolah sesuai dengan model pembelajaran yang digunakan guru. Sehingga bisa memaksimalkan hasil belajar IPS. Selain itu Sekolah hendaknya mampu melengkapi fasilitas di dalam kelas seperti peta, globe, dan mengijinkan serta memfasilitasi siswa pada proses pembelajaran IPS dapat keluar kelas sebagai proses pembelajaran pada mata pelajaran IPS.
\end{abstract}

\begin{abstract}
The purpose of this study is to determine the effect of learning models on IPS Learning Outcomes. The object of research includes student and teacher of class VII State Junior High School in Gunungpati District. The approach use in this research is quantitative Expost Facto. Data collection method use in the form of questionnaires and documentation. While the data analysis technique use is regression analysis. The results showed that there is an influence between the learning model use by theacher to the result of the student of class VII State Junior High School in Gunungpati District. The result of calculation of simple regression analysis with equation got value $a=48,504$ and $b=0,364$ so by using simple linier regression equation formula as follows. $\hat{Y}=48,504+0,364 X$. Suggestion for teacher should be more varied using learning modelsin IPS learning. While students so be able to utilize school facilities in accordance with the model of learning use by teachers. So it can be maximized the results of IPS learning. In addition, school should be able to complete the projector facilities in the classroom, the maps as an IPS Learning medium, and allow and facilitate student in the learning process of IPS can be out of class as a processof learning in social study process. So that the learning model is more varied, not monotonous in the classroom.
\end{abstract}

(C) 2019 Universitas Negeri Semarang

\footnotetext{
Alamat korespondensi:

Gedung C1 Lantai 1 FIS Unnes

Kampus Sekaran, Gunungpati, Semarang, 50229
}

E-ISSN 2685-4929 
E-mail: jurnalsosioliumpips@mail.unnes.ac.id

\section{PENDAHULUAN}

Pelajaran IPS di tingkat Sekolah Menengah Pertama merupakan mata pelajaran yang mencakup materi cukup luas. Menurut Setyowati (75:2016) Kegiatan pembelajaran dalam kurikulum 2013 diarahkan untuk memberdayakan semua potensi yang dimiliki oleh peserta didik agar mereka memiliki kompetensi yang diharapkan melalui upaya menumbuhkan sikap, keterampilan, dan pengetahuan. Guru diharuskan menyelesaikan target ketuntasan belajar peserta didik, sehingga perlu perencanaan dan pelaksanaan pembelajaran dengan menggunakan model, metode, media atau alat peraga dan strategi belajar yang tepat, guru juga harus mampu memahami karakteristik peserta didik dan memberikan rangsangan kepada peserta didik agar bersemangat dalam mengikuti proses pembelajaran IPS di Sekolah Menengah Pertama.

Kurikulum 2013 (K-13) adalah kurikulum yang berlaku dalam Sistem Pendidikan Indonesia. Kurikulum ini merupakan kurikulum yang telah ditetapkan oleh pemerintah untuk menggantikan Kurikulum 2006 (yang sering disebut sebagai Kurikulum Tingkat Satuan Pendidikan). Menurut Nisa (2016:62) Guru harus siap dengan adanya Kurikulum 2013 yang sudah dilaksanakan saat ini dan akan terus diimplementasikan pada periode-periode selanjutnya. Dalam implementasi kurikulum 2013, guru dituntut untuk menggunakan model pembelajaran yang inovatif. Pembelajaran berbasis kurikulum 2006 guru sebagian besar menggunakan model pembelajaran ceramah. Oleh karena itu, diperlukan pembelajaran yang bervariasi dan menarik dalam proses pembelajaran. Tujuannya agar dapat mempermudah peserta didik dalam memahami materi. Selain itu, peserta didik tidak merasa bosan dengan metode pembelajaran guru yang bersifat monoton.

Kondisi dunia sekolah masih banyak guru yang menggunakan metode ceramah dalam mengajar IPS. Seperti yang terjadi pada SMP Negeri di Kecamatan Gunungpati. Guru IPS Kelas VII masih sering menggunakan model pembelajan ceramah. Padahal sejak diberlakukannya kurikulum 2013, guru dituntut menggunakan model pembelajaran yang bervariasi agar siswa aktif dalam pembelajaran. Berdasarkan hasil wawancara pada tanggal 22 Januari 2018 dengan Ibu Isti selaku guru mata pelajaran IPS SMP 24 Semarang di Kecamatan Gunungpati Kota Semarang, metode ceramah masih dianggap ampuh dalam mengajar pembelajaran IPS. Hal itu dikarenakan sebagian besar materi IPS bersifat hafalan. Selain itu, peserta didik lebih mudah konsentrasi dalam menerima materi jika guru menjelaskan melalui metode ceramah. Dengan keadaan seperti itu, bukan berarti guru tersebut belum mencoba menggunakan model pembelajaran selain ceramah. Dalam proses pembelajaran menggunakan model pembelajaran selain ceramah, banyak peserta didik yang tidak kondusif. Hal ini terjadi ketika guru sudah siap mengimplementasikan model pembelajaran yang bervariatif akan tetapi model tersebut tidak sesuai dengan keadaan peserta didik di suatu kelas.

Beberapa permasalahan di atas yang menyebabkan setiap guru menerapkan berbagai model pembelajaran yang efektif diterapkan kepada peserta didik. Berbagai model pembelajaran yang digunakan guru dalam mengajar IPS tersebut memberikan pengaruh terhadap hasil belajar IPS. Namun penggunaan model-model pembelajaran juga disesuaikan terhadap kondisi peserta didik dan materi pembelajarannya.

Penelitian ini bertujuan untuk mengetahui seberapa besar pengaruh model pembelajaran yang digunakan guru IPS terhadap hasil belajar peserta didik. Seberapa besar prosentase model pembelajaran yang efektif terhadap hasil belajar peserta didik SMP Negeri di Kecamatan Gunungpati. 


\section{METODE}

Penelitian ini menggunakan pendekatan kuantitatif. Jenis penelitiannya yaitu Ex-PostFacto. Menurut Widiarto dalam jurnalnya yang berjudul "Penelitian Ex Post Facto" tahun 2013, penelitian Ex Post Facto bertujuan menemukan penyebab yang memungkinkan perubahan perilaku, gejala atau hal-hal yang menyebabkan perubahan pada variabel bebas yang secara keseluruhan sudah terjadi.

Terdapat banyak cara maupun rumus untuk menentukan jumlah sampel, salah satunya adalah menggunakan rumus Slovin yang sederhana dan mudah dihitung. Rumus Slovin Secara Matematis, Rumus Slovin yang kita gunakan untuk menentukan jumlah sampel adalah sebagai berikut (Purnomo,2010:77) :

Keterangan :

$$
\mathbf{n}=\frac{\mathbf{N}}{1+\mathbf{N} e^{2}}
$$

$\mathrm{n}=$ Jumlah Sampel

$\mathrm{N}=$ Jumlah Total Populasi

$\mathrm{e}=$ Batas Toleransi Error

Dalam penelitian ini, yang menjadi populasi adalah peserta didik kelas VII SMP Negeri di Kecamatan Gunungpati. Unit sampel utamanya tentu beberapa peserta didik kelas VII SMP Negeri di Kecamatan Gunungpati, yaitu SMP 24 Semarang, SMP Negeri 22 Semarang, dan SMP Negeri 41 Semarang (Guru kelas VII dan Peserta didik). Menurut Purwanto (2008:257) teknik penetapan purposive sampling adalah pengambilan sampel yang di lakukan dengan memilih secara sengaja menyesuaikan dengan tujuan penelitian.

Alat pengumpulan data penelitian ini adalah angket dan dokumentasi. Analisis data yang digunakan yaitu teknik analisis regresi.

\section{HASIL DAN PEMBAHASAN}

Hasil jawaban siswa mengenai model pembelajaran yang digunakan guru disusun dengan menggunakan tabel frekuensi (Sugiyono, 2010: 33).
Model Pembelajaran yang digunakan Guru IPS Kelas VII SMP Negeri di Kecamatan Gunungpati Semarang

diperoleh informasi dari total jumlah siswa 474 yang menjawab kuesioner bahwa 188 siswa yang memilih sangat setuju $(39,66 \%), 246$ siswa (51,89\%) menjawab setuju, 37 siswa $(7,80 \%)$ menjawab kurang setuju, 2 siswa $(0,42)$ menjawab tidak setuju dan 1 siswa $(0.21 \%)$ menjawab sangat tidak setuju. Model pembelajaran yang digunakan guru berpengaruh terhadap hasil belajar siswa. Variabel Model pembelajaran yang digunakan guru berpengaruh terhadap hasil belajar siswa dikategorikan setuju, hal ini dapat dilihat dari rata - rata skor sebesar 74,16.

model pembelajaran ceramah bervariasi masih sering digunakan dalam pembelajaran IPS karena dipengaruhi beberapa faktor. Faktor tersebut diantaranya yaitu kondisi peserta didik yang tidak kondusif atau sulit diatur. Selain itu, keterbatasan kemampuan guru dalam membuat media pembelajaran yang lebih menarik juga menghambat pelaksanaan model pembelajaran menggunakan model pembelajaran aktif. Sebagian besar guru IPS Kelas VII SMP Negeri di Kecamatan Gunungpati belum melaksanakan pembelajaran sesuai dengan RPP yang disusun. Mereka menyusun perencanaan pembelajaran IPS menggunakan model pembelajaran aktif, namun pelaksanaannya masih menggunakan model ceramah bervariasi. Walaupun ada juga guru yang sudah mengimplementasikan pelaksanaan model pembelajaran sesuai dengan perencanaan yang disusun. Model pemebelajaran aktif yang sering digunakan yaitu diskusi aktif.

\section{Hasil Belajar IPS Kelas VII SMP Negeri di Kecamatan Gunungpati Semarang}

Hasil belajar secara kognitif peserta didik kelas VII di SMP Negeri 24 semarang diambil dari nilai Ulangan Akhir Semester Genap tahun 2017/2018. Rata-rata nilai IPS peserta didik yaitu 69,86. Secara afektif dan psikomotorik peserta didik kelas VII SMP Negeri di Kecamatan Gunungpati sudah cukup baik. 
Siswa sudah berdoa sebelum dan sesudah aktivitas.

Pengaruh Model Pembelajaran yang digunakan Guru terhadap Hasil Belajar Siswa Kelas VII SMP Negeri di Kecamatan Gunungpati Semarang.

Angket (kuesioner) tentang model pembelajaran yang telah dikerjakan siswa digunakan untuk mengetahui pengaruh model pembelajaran yang digunakan guru IPS terhadap hasil belajar siswa. Pengaruh model pembelajaran yang digunakan guru terhadap hasil belajar siswa ini dianalisis menggunakan analisis regresi linier sederhana. Hasilnya dapat menggambarkan pengaruh model pembelajaran (X) terhadap hasil belajar siswa (Y).

Hasil perhitungan analisis regresi sederhana dengan persamaan didapatkan nilai a $=48,504$ dan $\mathrm{b}=0,364$ sehingga dengan menggunakan rumus persamaan regresi linier sederhana sebagai berikut.

$$
\hat{\mathrm{Y}}=48,504+0,364 \mathrm{X}
$$

\section{KESIMPULAN}

Berdasarkan hasil penelitian dan pembahasan mengenai pengaruh model pembelajaran yang digunakan guru terhadap hasil belajar siswa kelas VII SMP Negeri di Kecamatan Gunungpati dapat disimpulkan sebagai berikut:

Model Pembelajaran yang digunakan guru IPS Kelas VII SMP Negeri di Kecamatan Gunungpati yaitu model pembelajaran aktif seperti diskusi, jigsaw, dan model pembelajaran ceramah bervariasi.

Hasil belajar siswa SMP Negeri di Kecamatan Gunugpati memiliki rata-rata nilai kognitif sebesar 69,86 .

pengaruh model pembelajaran yang digunakan guru terhadap hasil belajar siswa kelas VII SMP Negeri di Kecamatan Gunungpati adalah:

$$
\hat{\mathrm{Y}}=48,504+0,364 \mathrm{X}
$$

Dengan kata lain ada pengaruh model pembelajaran yang digunakan guru terhadap hasil belajar siswa kelas VII SMP Negeri di Kecamatan Gunungpati.

\section{DAFTAR PUSTAKA}

Nisa, Aisyah Nur Sayidatun. 2016. Analisis Kesiapan Guru IPS di SMP se-Kecamatan Bawang Banjarnegara dalam Mendukung Implementasi Kurikulum 2013. Semarang : Pendidikan IPS FIS UNNES dan MGMP IPS PKN Kota Pekalongan. Harmony Vol .1 No. 1 Hal. 62

Purnomo, Arif. 2010. Metodologi Penelitian Pendidikan. Semarang: UNNES

Purwanto. 2007. Metodologi Penelitian Kuantitatif. Yogyakarta: Pustaka Pelajar.

Setyowati, Rini dan Endang Mulyani. 2016. Efektivitas Pendekatan Scientific dengan PBL dan Problem Solving untuk Meningkatkan Kompetensi dalam Pembelajaran IPS : Jurnal Pendidikan IPS UNY. Harmoni Sosial Vol. 3 No. 1 Hal. 75

Sugiyono. 2015. Metode Penelitian Pendidikan. Bandung: Alfabeta. 